\title{
Ghosts of the Past in the Present in the Narratives of Diaspora
}

\author{
Ubaraj Katawal \\ Associate Professor of English, \\ Valdosta State University, USA
}

Eva Hoffmann, the Polish-American author, writes, "In our current, habitually diasporic, habitually nomadic world, the oppositional, bipolar model no longer holds" (Aciman 55). How does the past-present continuum work in this "habitually nomadic" experience? Can diasporic people forget the past as another country, or is it the present that is more foreign? How do the narratives of diaspora dramatize the past-present dynamic, and how do memories of the past affect the present?

Unlike what many people believe that one can forget their past if they try, I argue that the past and present intertwine inextricably for an exile. "The ghostliness [of the past] was merely the absence of time and distance," as a character in Amitav Ghosh's The Shadow Lines notes (178). The "ghostliness" of the past affects the present, even though what it is that is affected is hard to verbalize. In line with Arjun Appadurai's assertion that "one man's imagined community is another man's political prison" (Braziel 30), I argue in this essay that diasporic experience is historically contingent. This, however, does not mean that past experiences are meaningless, but rather that the ghosts of the past define the present as much as the present modifies the past. I develop this argument through a literary analysis of fictions of diaspora.

In his book Black Skin White Masks (1967), Frantz Fanon discusses the dilemma of a black man in the colonial world. Torn between the past and the present, the mother country and the native country, tradition and modernity, black culture and white culture, a Martiniquais finds it hard to identify with any particular class and category. A black man can either identify with the mother culture and be assimilated; or try to negate the home culture and stick to the old one. In either case, he fails to disalienate himself from society. If he identifies with the white culture and starts acting like a white man, he is ridiculed for being a mimic man. If, alternatively, he refuses to assimilate in the white culture, he is automatically excluded from the mainstream culture. Fanon points out that "there is no reason why Andre Breton should say of Césaire ["a Negro poet with a university degree"], 'Here is a black man who handles the French language as no white man today can"' (39), except to suggest some form of disbelief that a black man can speak the white man's language fluently. Even if the black man wants to forget his native culture, he is constantly reminded by the whites of his "proper" place: "I discovered my blackness, my ethnic characteristics; and I was battered down by tom-toms, cannibalism, intellectual deficiency, fetishism, racial defects, slave-ships, and above all: 'Sho' good eatin'" (Fanon 112). Sticking with the old culture is no solution either, as not only the white but also the native people look down on him for not learning the mother culture; in other words, a black man — or an immigrant, for that matter-necessarily carries a double consciousness. 
If in terms of race, the colored and the white have different experiences, they share a similar experience in terms of temporal dynamic, however. The past-present continuum applies to all, irrespective of other classificatory predicates. To quote Fanon again, "Those Negroes and white men will be disalienated who refuse to let themselves be sealed away in the materialized Tower of the past. For many other Negroes, in other ways, disalienation will come into being through their refusal to accept the present as definitive" (226). Fanon suggests that neither the past nor the present stand alone as definitive, but work as mutual qualifiers: that the past shapes the present as much as the present transforms people's understanding of the past. The intersection of the past and the present provides people with pathways for a better future. As Fanon convincingly states, "If the question of practical solidarity with a given past ever arose for me, it did so only to the extent to which I was committed to myself and to my neighbor to fight for all my strength so that never again would a people on the earth be subjugated" (227). For Fanon, there is no black men's mission or white men's burden (228).

Toni Morrison dramatizes the predicament of people who try to found a community based on a mission of purity in her novel, Paradise. The patriarchs of the newly founded black community, Ruby, look into their past with anger and vengeance"they carried the rejection of 1890 like a bullet in the brain" (109). After Haven, their old establishment, fails to fulfill the mission of the Old Fathers, the new Fathers, led by the twin, Deacon and Steward Morgan, try everything so that they do not repeat the failures of the past in the new "Paradise," i.e. Ruby. Ironically, while trying to move away from the white men's oppressive racism, they happen to repeat unconsciously the same mistakes by disallowing the Convent women, who live at the outskirt of the city, from participating in their community activities. As if the exclusion were not enough, they later resort to violence to get rid of them. Moreover, a white family perishes in a blizzard not far from Ruby after the black folks refuse to provide them a shelter.

As Morrison rhetorically asks elsewhere, "Why should a young country repelled by Europe's moral and social disorder, swooning in a fit of desire and rejection, devote its talents to reproducing in its own literature the typology of diabolism it wanted to leave behind?" (Playing 36). If the United States reproduced the diabolism of Europe in its racism and the extermination of the Native Indians, the black rulers of Ruby reproduce it by killing their own "others:" such as the inhabitants of the Convent. "Not existence but knowledge is without hope," write Max Horkheimer and Theodore Adorno (28). The twins' memory of their painful past negatively affects them in their present. As Susan Strehle puts it, "In the struggle to 'convert a racist house into a race-specific yet nonracist home,' Ruby practices a racial exclusiveness that reproduces the assumptions and ratifies the separations in the surrounding white culture" (52). By showing this reiteration of will to domination in both black and white cultures, Morrison demonstrates the danger of the legacy of the past in the present.

Similarly, Andrew McGahan's The White Earth (2004) delves into the psychology of a character, John McIvor, who tries to instill the legacy of the white guilt onto a young boy of about nine. McIvor inherits his own legacy of guilt and humiliation from the past. A settlement founded by the social outcasts of Europe, Kuran, where 
McIvors seek their fortunes, becomes a grave for the Aborigines. John's father, Daniel, works for the White owner of Kuran Station. He tries to do every thing possible to inherit the White land, such as having a son to eventually make him marry with the White heiress and killing the black, Aboriginal people. As Ruth, John McIvor's daughter, puts it:

No one knows exactly how many of them there were. But when your father arrived, you were standing there screaming at them, scared out of your wits by the black men. They were naked, someone told Malcolm, and all painted up. I guess they were the first Aborigines you'd ever seen. But your father knew them, it was those same damn trespassers again, all naked and wild, threatening his boy. And he had his gun. It's no surprise what happened. (348)

At last, all Daniel and John inherit are loss and humiliation for Elizabeth, the heiress of the White legacy, who dismisses both the father and the son from Kuran Station. "You were ever an employee, Mr. McIvor" (55), Elizabeth tells Daniel. This same humiliation drives the young John McIvor to acquire the property at any cost, even at the banishment of his own family. At the end, McIvor attains his materialistic goal in becoming "the chosen one" but that costs him his soul. The white man's burden proves too heavy carry on.

Both the Morgan brothers in Morrison's Paradise and McIvor in The White Earth try to either carry over too much from the past, like humiliation, or too little as they fail to see and correct their past mistakes. These characters attain their materialistic goals but lose their humanity in the process. As a character in Paradise reflects, "Almost always, these nights, when Dovey Morgan thought about her husband it was in terms of what he had lost. His sense of taste one example of the many she counted. Contrary to his (and all of Ruby's) assessment, the more Steward acquired, the more visible his losses" (82). For his part, John McIvor abandons his family for the squatter mansion. "Men have ceased to consider their purpose and fate" (216), write Horkheimer and Adorno. The Morgans and McIvors forget their purpose and their fate while avenging their ancestor's bitter experience of being excluded.

In their important essay on Enlightenment, entitled "The Concept of Enlightenment," Horkheimer and Adorno argue that the logic behind the Enlightenment project is the will to domination. They show the seeds of domination motives in the mythic and magic world in the pre-Socratic time. The actions of Odysseus show, Horkheimer and Adorno pin-point, how the Greek hero exploits both nature and other men in order to preserve his self from the potential destruction (34). During his return from the Trojan War, he resists the threat from the Sirens by asking his crews to tie him on the boat. Odysseus' resistance to the pleasure offered by the Sirens' music suggests his intention to dominate the irrational nature through his rational mind; he also controls and exploits the crews to accomplish his mission. The Sirens represent the pleasurable but destructive forces to be avoided for the unity and preservation of the Odysseus' self.

The mission or the burden to destroy the unwanted forces, however, always remains incomplete. This is why, the ghosts of the Convent women appear in Morrison's 
Paradise and the bones of black men are found unconsumed by fire in The White Earth, showing that any attempt to bury the past is doomed to fail.

Saleem Sinai, the narrator of Salman Rushdie's Midnight's Children (1981), struggles with the past guilt and humiliation. Born a bastard son from the illicit relationship between an English landlord and a poor Indian woman, Saleem never gets rid of his inheritance of loss. He ends up in the rich family of Ahmed and Amina Sinai due to the whimsical and unlawful act of Mary Pereira, who exchanges the babies in the hospital to appease her revolutionary lover Joseph D'Costa, "her own private revolutionary act, thinking He will certainly love me for this, as she changed name-tags on the two huge infants, giving the poor baby a life of privilege and condemning the rich-born child to accordions and poverty" (117). As the truth of his real parentage comes to light later in his life, Saleem feels guilty for depriving Shiva, the real inheritor, of the Sinai estate. Born with a snotnose, he carries the guilt of past along with his nicknames, as he relates in the beginning of his story, "I, Saleem Sinai, later variously called Snotnose, Stainface, Baldy, Sniffer, Buddha and even Piece-of-the-Moon, had become heavily embroiled in Fate - at the best of time a dangerous sort of involvement" (9).

Saleem's hybrid identity inherited from his English father, poor Indian mother, and the adopted Sinai family always makes him feel unhomely. As Homi Bhabha writes: "The negating activity is, indeed, the intervention of the 'beyond' that establishes a boundary: a bridge, where 'presencing' begins because it captures something of the estranging sense of the relocation of the home and the world - the unhomeliness - that is the condition of extra-territorial and cross-cultural initiations" (9). Saleem bridges the inside and the outside by his special physical and mental attributes. The physical bridge that links him with the outside world is his nose. Considered as a physical deformity by the medical world, his mega-nose proves to be his gift not only to link himself with his grandfather, Aadam Aziz, but also to negate the rationalizing powers of the Widows, i.e. the powers-that-be, and the-land-of-the-pure. Of the nose, Horkheimer and Adorno write:

[...]The nose - the physiognomic principium individuationis, symbol of the specific character of an individual, described between the lines of his countenance. The multifarious nuances of the sense of smell embody the archetypal longing for the lower forms of existence, for direct unification with circumambient nature, with the earth and mud. Of all the senses, that of smell - which is attracted without objectifying - bears clearest witness to the urge to lose oneself in and become the "other." As perception and the perceived - both are united-smell is more expressive than the other senses. When we see we remain what we are; but when we smell we are taken over by otherness. Hence the sense of smell is considered a disgrace in civilization, the sign of lower social strata, lesser races and base animals. (184)

Both Aziz and Saleem have big noses but whereas Aziz hurts his nose literally and metaphorically — as he disregards the warning of Tai, the boatman, who hates Aziz's Heidelberg bag (symbol of Western civilization) - Saleem uses it as an uncanny instrument of power against instruments of the Enlightenment. Tai reminds Aziz the value of having a big nose: "You know what this is nakkoo? It's the place where the 
outside world meets the world inside you. If they don't get on, you feel it here. Then you rub your nose with embarrassment to make the itch go away. A nose like that, little idiot, is a great gift. I say: trust it. When it warns you, look out or you'll be finished. Follow your nose and you'll go far'" (17-18). Saleem follows his nose, even though he faces many hurdles in the way. As opposed to the physical power of the knee and the gun employed by his alter-ego, Shiva, who like John McIvor, turns violent and paranoiac against the weak, Saleem follows his nose to create oppositional and alternative narratives of the world. Saleem's alternative ordering provides a "negating activity," to use Bhabha's term, that shows that an alternative understanding of the world to the one that is made available by the Enlightenment is not only possible but also necessary to survive the religious and political Manicheanisms. Classifying smells by color seems strange but upon further reflection, the matching of betrayal with the heavyweight stink of earth makes a lot of sense.

Regarding Rushdie's espousal of a heterogeneous view of the world, Paul Gilroy writes, "His [Rushdie's] experiences are also a reminder of the difficulties involved in attempts to construct a more pluralistic, postcolonial sense of British culture and national identity" (Braziel 58). Saleem's challenge to unravel the fake partitions of the world is also Rushdie's. Gilroy further writes, "It is part of my argument that this inside/outside relationship should be recognized as a more powerful, more complex, and more contested element in the historical, social, and cultural memory [...] (Braziel 59). Critic Vijaya Mishra, in his essay, "Postcolonial Differend: Diasporic Narratives of Salman Rushdie," argues in line with Gilroy's view that human identity is more complex and shifting: "'Home' now signals a shift away from homogeneous nation-states based on the ideology of assimilation to a much more fluid and contradictory definition of nations as a multiplicity of diasporic identities" (Bloom 64). Although Mishra's discussion of the "Narratives of Salman Rushdie" is limited to The Satanic Verses (1988), I think his argument applies to Rushdie's other works as well, especially to Midnight's Children.

Saleem, like Saladin Chamcha in The Satanic Verses, gets mutilated in his multiple exiles. Theodor Adorno in Minima Moralia: Reflections on a Damaged Life (1951) notes, "Every intellectual in emigration is, without exception, mutilated [...]" (33). Saleem's spiritual and intellectual mutilation happens once his family moves to Pakistan, even though he had experienced multiple physical mutilations before his spatial exile. Once in Pakistan, his spirituality is literally degraded to the level of a dog; he works as a man-dog for the government's secret service unit founded to "root out undesirable elements" in East Pakistan (348). The government employs his nose to tame and control other oppositional subjects.

Saleem, however, disobeys the command and leads his team to an unknown place; he, unlike the fat man in Edwidge Danticat's title story, "The Dew Breaker," who becomes the slave of the murderous president and kills the preacher, goes against the government's intentions. Saladin Chamcha gets physically mutilated when he survives miraculously from the crash of Boeing 747 Bostan when the immigration officers torture Saladin even after finding out that he is a British citizen (164). Saladin, like Saleem, is neither at home in India, where his controlling father makes life unbearable, nor in Britain, where his appearance sets him apart from the rest of the population. These 
characters, like Willie Somerset Chandran in V.S. Naipaul's Half a Life (2001) and Magic Seeds (2004), float between the shadow lines of nations and classifications in the metaphorical "ships in motion across the spaces," in Gilroy's words (Braziel 52). The image of the moving ship stands for change, but it also reminds the travelers of the history of slavery that haunts the ship.

Towards the end of The Satanic Verses Saladin Chamcha notes that a ghost is "an Unfinished business" (540). He soon realizes, however, that if one gets lost in the tragic or nostalgic past, new things do not happen: "Let the bulldozers come. If the old refused to die, the new could not be born" (546). This is exactly what Shaila Bhave in Bharati Mukherjee's "The Management of Grief" feels when she loses her husband and two sons in a plane crash. Forced to choose between her duty towards her lost family and towards herself, the past and the present, Shaila chooses to move ahead with the present while her friend, Kusum, who has also lost her daughter in the same incident, returns to a traditional lifestyle. However, the past refuses to disappear for both Shaila and Kusum as their deceased family members come to visit them, similar to the reappearance of the past in the forms of ghosts in Toni Morrison's works, such as Beloved.

Horkheimer and Adorno write: "History is eliminated in oneself and others out of a fear that it may remind the individual of the degeneration of his own existence-which itself continues" (216). In other words, the rational classification of life in the age of Enlightenment requires that one forget the past in order to boost his or her market value in the present. This pressure is what makes the narrator in Amitav Ghosh's The Shadow Lines feel "the heavyweight stinks of earth" (in Saleem Sinai's "ordering") when he is not informed of his grandmother's death because his exam is around the corner. He notes, "There seemed to be something fitting, after all, in the manner in which I had learnt of my grandmother's death: she had always been too passionate a person to find a real place in my late-bourgeois world, the world that I had inherited, in which examinations were more important than death" (90). As per Enlightenment principles, passion and emotion have no real value and the person in mourning poses immediate threat to a capitalistic lifestyle since such rituals nourish emotional feelings (Horkheimer and Adorno 216). The narrator of The Shadow Lines, much like Saleem, however, does not agree with such dominant worldview.

Let's face it: the past could be stifling as shown in Maxine Hong Kingston's The Woman Warrior: Memoirs of a Girlhood Among Ghosts (1975). Brave Orchid, the narrator's mother, literally fights with ghosts who haunt the girls' hostel at a medical school in China.

The ghosts in the novel embody fears that surround the women, whose roles in society are restricted. They are not supposed to live away from their family, let alone become doctors. Brave Orchid fights such fears or ghosts: "She pushed against the creature to lever herself out from underneath it, but it absorbed this energy and got heavier. Her fingers and palms became damp, shrinking at the ghost's thick short hair like an animal's coat [...]" (69). Brave defeats the social ghost—- "I do not give in" (70) - and later becomes a doctor. She then helps villagers to fight with diseases. Even after coming to America, however, Brave Orchid continues to fight against the ghosts, which now appear to her in different forms; all foreigners, the narrator remarks, are ghosts for the 
Chinese (93). Some immigrants gradually adapt to live with the "ghosts," while others like Moon Orchid, Brave's sister, do not and eventually disappear altogether.

In his celebrated essay, "Reflections on Exile," Edward Said discusses exile as a historically situated experience. Like Eva Hoffmann, mentioned at the beginning, Said underscores the fact that exile is a perpetual human experience. However, the degree of mass migration in the last few centuries brings the experience of exile into a sharp focus. He writes, "But the difference between earlier exiles and those of our own time is, it bears stressing, scale: our age-with its modern warfare, imperialism, and the quasitheological ambitions of totalitarian rulers - is indeed the age of the refugee, the displaced person, mass immigration" (174). The intra-national as well international wars have caused displacement of people from their "tradition, family and geography" in an alarmingly higher rate (Said 174). When the world becomes increasingly uninhabitable because of the perpetual wars of dominations, literature provides an alternative home for the intellectuals in exile. This option, sadly enough, is not available to all. Many of illiterate and underprivileged people live, like the old Sikh couple in Mukherjee's "The Management of Grief," with an eternal hope of returning home, of meeting with their family and friends. For them, the past and the present, the old culture and the new culture exist simultaneously, or "contrapuntally," to use Said's term (186).

Said further argues that even though exiles and refugees are cut off from their past, the past can never be severed completely from their psyche. He writes: "But note that Hugo twice makes it clear that the 'strong' or 'perfect' man achieves independence and detachment by working through attachments, not by rejecting them. Exile is predicated on the existence of, love for, and bond with, one's native place; what is true of all exile is not that home and love of home are lost, but that loss is inherent in the existence of both" (185). Said makes it clear that for an exile no home is permanent; rather every home is provisional and contingent. As he notes, "Exile is life led outside habitual order. It is nomadic, decentered, contrapuntal; but no sooner does one get accustomed to it than its unsettling force erupts anew" (186). Home is not only where one's heart is, but rather one's heart never feels at home in any one place as demonstrated in Samrat Upadhyay's works.

In Upadhyay's short story, “A Refugee,” Kabita, a young widow and refugee, is prepared to face her predicament on her own after she comes to Kathmandu with her four-year-old daughter. First, she works in a gift shop but she quits the job to give more time to her daughter. She, then, starts living in a one-room flat in Bagbazar, where Pitambar finds her and takes her to stay with his family in Dharahara. Earlier, he had been informed of Kabita's arrival in the city by his old friend, Jaikanath, in a letter asking Pitamber to see if he could do anything for her. For now, Kabita and her daughter feel at home with Shailaja, Pitamber's wife, even though Sumit, their twelve-year-old son, feels uncomfortable with the guests in the house. Shailaja helps Kabita to find a job at a Seamstress'. Life seems to be back to normal to Kabita, as her daughter, Priya, gets accustomed to her new home, until one day when Sumit accuses his father of keeping a second wife in their flat. Pitamber, offended at his son's remarks, hits him making him unconscious. The incident unsettles Kabita's illusion of finding a permanent home, prompting her to move out to a different apartment with her daughter. 
While characters in Upadhyay's “A Refugee,” Rushdie's The Satanic Verses, and Chimamanda Ngozi Adichie's Half of a Yellow Sun suffer from the intra-national conflicts and work through their predicaments, others as in Ghosh's The Shadow Lines, Rushdie's Midnight's Children, Helena Maria Viramontes' Under the Feet of Jesus cross the national borders but encounter a similar predicament of othering and unhomliness. In Under the Feet of Jesus, immigrants struggle with the "ghosts" in the forms of poverty, family separations, othering, death and destructions in the United States near the USMexico border. Petra, a mother of five, struggles to settle down with an old man, Perfecto, after her husband disappears, presumably for another woman. As the novel begins, we see Petra's family moving to a new location, trying to leave behind feuds with the neighbors. Estrella, the first of Petra's children, muses: "They were seven altogether - their belongings weighed down an old Chevy Capri station wagon, the clouds above them ready to burst like cotton plants. Then the barn disappeared into a hillside of brittle bush and opuntia cactus as the man who was not her father maneuvered the wagon through a laborious curve" (3). In two parallel attempts to establish a family, between Petra and Perfacto, on the one hand and between Estrella and Alejo, on the other, the characters try hard to hold the family together. Towards the end, the attempts to start and retain a stable family seem impossible as Estrella returns home after Alejo is hospitalized for "daño of the field," without much hope of reunion, and Perfecto constantly thinks of returning to his old homeland and family, leaving Petra to fend for her family alone, even though she is pregnant of his child. The spirit of Perfecto's dead wife visits him as frequently as Petra's hallucination of seeing her now lost husband. The novel ends with an antithetical situation when Perfecto once again stays outside the house, likely thinking of leaving Petra and her children, while Estrella sits on a barn roof like an angel trying "to summon home all those who strayed" (176). As Arjun Appadurai articulates it, this is a world "in which both points of departure and points of arrival are in flux, and thus the search for steady points of reference, as critical life-choices are made, can be very difficult" (Braziel 42). Instead, the intersection of "fort/da," coming and going, homeliness and unhomeliness, past and present constitutes the stories of tourists, immigrants, guest workers, urban squatters, students, exiles, and all other moving and displaced persons.

Appadurai argues that experiences of moving ideas, images and groups of people are not easy (Braziel 25-48). Exchanges of ideascape, mediascape, ethnoscape, technoscape, and financescape at a transnational level unsettle the notion of fixed indentities. Appadurai further writes, "Deterritorialization, in general, is one of the forces of the modern world, since it brings laboring populations into the lower-class sectors and spaces of relatively wealthy societies, while sometimes creating exaggerated and intensified senses or criticism to politics in the home state" (Braziel 35). The culture of exclusivity, similar to what Appadurai somewhere calls "predatory identities" (Fear 51), has led to the mass murder of the "outsiders," who do not fall within the dominant group's criteria of purity, well-dramatized by Morrison, Rushdie and others, and elaborated by Horkheimer and Adorno in their essay, "Elements of Anti-Semitism: The Limits of Enlightenment." It is premature to think, in other words, that nationalistic views of one's culture is completely taken over by a fragmented sense of time, space and culture, even though, the exponential mass movements of people have constantly de- 
established fixed notions of cultural and national identities. Moreover, there is always the chance that a victim in one historical context may turn into a compulsive murderer in another. As Horkheimer and Adorno remind us: "Anger is discharged on defenseless victims. And since the victims are interchangeable according to circumstances-gypsies, Jews, Protestants, Catholics, and so on - any one of them may take the place of the murderers, with the same blind lust for blood, should they be invested with the title of the norm" (171). The fear and bitterness of the one-time victims, the Morgan brothers in Paradise, John McIvor in The White Earth, the fat man in "The Dew Breaker," the judge in Kiran Desai's The Inheritance of Loss and many others, bear witness to this reality.

The judge, Jemubhai Popatlal Patel, in The Inheritance of Loss humiliates Gyan in

India because the former was humiliated by people in England:

Lastly, who was his [Jemubhai's] favorite writer?

A bit nervously for he had none, he replied that one was fond of

Sir Walter Scott. [....]

"Can you recite one of your favorite poems for us?" asked a professor of social anthropology. [....]

When he looked up, he saw they were all chuckling. (124)

He mistreats his wife as badly as he was mistreated by others in England. At last, mimicking his former masters, Jemubhai establishes a more congenial relationship with a dog than with his wife and his granddaughter, Sai. He ends up reproducing similar colonial practices of the white men that othered and victimized him in the first place.

Once again, Said reminds us that "the metropolis gets its authority to a considerable extent from the devaluation as well as the exploitation of the outlying colonial possession" (qtd. in Prakash 37). And to repeat Morrison's question: "Why should a young country repelled by Europe's moral and social disorder, swooning in a fit of desire and rejection, devote its talents to reproducing in its own literature the typology of diabolism it wanted to leave behind?" (Playing 36). She dramatizes the paranoia in her novel, Paradise as well, where in place of the white men, the black men, who are the rulers now, destroy their weakest neighbors, the Convent women. I would also argue that while trying to critique the evils of British colonialism, Kiran Desai reproduces the same "typology of diabolism" she wanted to leave behind in her criminalization of Nepali culture and identity through her seminar work, The Inheritance of Loss.

Utilizing not with vengeance but with an openness for change, the past proves to be positive, however. The memory of Tridib connects the narrator of The Shadow Lines with May, who tells him the story of how Tridib died in a riot while trying to protect her. Like Shaila Bhave in Mukherjee's "The Management of Grief," May moves on with the present, even though she is constantly reminded of her guilt in Tridib's death. She comes to realize that Tridib died for people to emancipate them from the petty conflicts based on one's identitarian epithets. These characters cannot disown their past, neither can they deny the pressure of the present. As Said informs us aptly, "The relevance of T. S. Eliot's 
remarks in 'Tradition and the Individual Talent' about the historical sense are demonstrably important" (qtd. in Prakash 33). Forgetting the past is to repeat the mistakes done in the past.

It is true, as Morrison makes us aware in Paradise, that people can repeat the same mistakes of past while trying to escape them. America's imperialism in the world and India's expansionism in South Asia are the consequences of denying inheritance of the past, of its deliberate misreading. However, used positively, the past can also be more constructive as demonstrated in The Shadow Lines. The narrator, who is a Westerneducated Indian, likes May, an English memsahib, who suffers from the guilt of causing Tridib, her admirer/lover's death in a communal riot. The union of the narrator and May at the end portends a better, if not less complex, relationship between the East and the West, between the past and the present.

It is, however, necessary to note that one does not experience the continuum between the past and the present, tradition and novelty, old culture and the new culture with one's conscious choice but because of an individual's contingency. As Lisa Lowe argues regarding the Asian-American identity:

Hybridization is not the "free" oscillation between or among chosen identities. It is the uneven process through which immigration communities encounter the violences of the US state, and the capital imperatives served by the United States and by the Asian states from which they come, and the process through which they survive those violences by living, inventing, and reproducing different cultural alternatives. (Braziel 151)

In her novel, Typical American, Gish Jen thematizes the way immigrant communities define themselves depending on their given economic, political and cultural contingencies. Ralph (Yifeng) Chang, Theresa Chang and Helen (Hailan) Chang form a family after they meet in New York City. Trying to escape the persecution of the Chinese government, they attempt to adjust in the new homeland, America, despite Ralph's initial struggle with his immigration documents. Before leaving his family in China, Ralph makes a list of goals for himself to be accomplished in America. However, three weeks into the new culture and environment, he falls prey to the same aspect of American life that he feared the most: loneliness. He ends up drifting in the street in New York City, before he meets his elder sister, Theresa at a park. He marries Theresa's friend, Helen, and the three of them start their journey to fulfill their American Dream. Anything they find new, they call it typical American, including the unique characteristics of people they meet. Eventually, Ralph completes his doctoral degree in mechanical engineering and becomes a tenured professor, Theresa completes her M.D. and starts practicing at a local hospital and Helen gives birth to Callie and Mona. Their American dream seems to have been complete once they buy a house and a car for the family. In reality, it is far from being complete. For, their ambition quickly takes a downward turn as Ralph leaves his job to start a business that has legal issues, and Theresa and Helen begin to have affairs. They are preoccupied either with either sex or money. Ralph teaches his daughters the value of money: "Money. In this country, you have money, you can do 
anything. You have no money, you are nobody. You are Chinaman! Is that simple" (199). Ironically, his American dream slips away when his business collapses, family disintegrates and he almost kills Theresa in a car accident. Finally, he comes to realize his limits and the story closes as the family comes together once again with perhaps an alternative understanding of their identities and the American dream. Ralph reflects toward the end: "He could not always see, could not always hear. He was not what he made up his mind to be. A man was the sum of his limits; freedom only made him see how much so. America was no America" (296). Yet, when he thinks of his sister's happiness - that she finds with Old Chao - in America, which was unimaginable in the traditional Chinese culture, he feels torn between the past and the present, the old and the new world; Ralph becomes a "subject-effect," in Spivak's term (qtd. in Guha 341), of his situatedness.

Ralph's situation may not be sold as a typical Asian American immigrant experience, however. His friend, Grover Ding, born and raised in America, shows different aspect of Asian American identity, which is marked by sexual adventures, suspicious business dealings and squander. Even the first generation immigrant, Old Chao, is different from Ralph: while Ralph puts making money as his top priority, Old Chao, like Mrs. Das in Jhumpa Lahiri's "Interpreter's Maladies," risks everything for a sexual adventure. The fact then that every immigrant has different historical and material conditions negates the idea of homogeneous immigrant experiences. However, demanded by the same historical and material conditions, immigrants can also come together to fight a common cause. As Lowe suggests, "Asian Americans can articulate distinct challenges and demands based on particular histories of exclusion and racialization, but the redefined lack of closure - which reveals rather than conceals differences - opens political lines of affiliation with other groups in the challenge to specific forms of domination insofar as they share common features" (Braziel 141).

In The Satanic Verses, Rushdie best showcases the material differences between two characters, who come from similar cultural and historical backgrounds. An immigrant from India, Salahuddin Chamchawala a.k.a. Saladin Chamcha leaves his old home country to avoid invasion of his privacy by his abusive father. In England he marries a white girl, Pamela Lovelace, and works as an artist in Radio and TV programs. He seems to have been enjoying his new homeland until he tumbles from a crashing plane and miraculously lands alive, and is subjected to torture from immigration and police officers. The only other survivor of the terrorist blast of the plane, named Bostan is Gibreel Farista (born as Ismail Najmuddin), a legendary film actor in pursuit of Alleluia Cone, who is a "climber of mountains, vanquisher of Everest, blonde yahudan, ice queen" (Satanic Verses 31). Gibreel is an orphan, born to poor parents who make their living by running lunch-boxes to workers in a Bombay slum. After his parents' deaths, he is adopted and introduced to the film industry by Babasheb Mhatre; Gibreel becomes a superstar quickly and starts having promiscuous relations with his lady fans. One of whom, Rekha Merchant, commits suicide after he dumps her. In London, he meets and stays with Alleluia Cone, but the ghost of Rekha Merchant visits him wherever he goes. 
Gibreel refuses to help Saladin when the latter is captured by the immigration officials right after the fall from the Bostan. This betrayal prompts Saladin later to break up the relationship between Gibreel and Alleluia. Saladin and Gibreel become the most dangerous enemies to each other, not only because they have different experiences in England, but also because of the pressure of their present condition. Had Gibreel tried to defend Saladin from the immigrant officers, he would himself end up in a similar predicament. Gibreel, however, saves Saladin while the latter is being burnt alive in the Shaandaar Café, even after knowing that Saladin had played a role in the former's strained relationship with Alleluia. To cut a long story short, the novel showcases a complex relationship among the Indian diaspora in London, full of differences and disjunctures; at the same time they come together to fight a common cause of the ethnic and racial discrimination in London, as in the recent arrest of Dr. Uhuru Simba, a black man who is been charged of being the "Granny Ripper," a serial killer of elderly women in the city.

In one of the most telling moment in the novel, Saladin notes: "Why demons, when man himself is a demon?' the Nobel Laureate Singer's 'last demon' asked from his attic in Tishevitz. To which Chamcha's sense of balance, his much-to-be-said-for-andagainst reflex, wished to add: "And why angels, when man is angelic too?"' (408). When the memory of Gibreel's betrayal forces Saladin to act like a demon, he becomes an angel too by trying to help the people in distress. However, while some people, like Saladin, Henry Park in Chang-Rae Lee's Native Speaker, Ralph in Jen's Typical American, and Deacon Morgan in Morrison's Paradise, seem to have learnt from their past mistakes, others, like Gibreel Farista, Steward Morgan in Paradise, and the judge in The Inheritance of Loss, either consciously try to ignore the past or it has already been too late for them to change. Nevertheless, characters who change after learning from their past mistakes seem to prevail in the end.

The ending of Upadhyay's novel, The Guru of Love best epitomizes the pastpresent continuum in the narratives of diaspora. After a long family turmoil brought on himself by Ramchandra, a married man with a loving wife, son and daughter because of his love adventures with a poor single mother, Malati, the story closes with a family reconciliation where Ramchandra is once again with his family and Maliti starts living with her daughter's father.

Eleven years later, Ramchandra encounters Malati during one of his morning walks. Ramchandra wants to greet her but something holds him back: Malati's daughter, who is the same girl that he played with eleven years ago, but now with something new about her, that she is an adolescent, who can call out their secret meeting. In the last paragraph, the narrator notes: "Malati was still talking to the woman when Ramchandra passed them. He deliberately walked slowly so that she would see him and call out, 'Sir, sir,' and he would turn around and exclaim his pleasure at seeing them and pat Rachana [her daughter] on the head. But nothing happened. He kept walking, and after about a hundred yards, turned around. She was no longer there" (290). Malati embodies the past that comes to Ramchandra, who feels unhomely within his own community, but not with 
the same meaning as it had several years ago. It comes with a change in the form of Rachana that prevents the subject from dangerously holding onto their past.

\section{Works Cited}

Adichie, Chimamanda Ngozi. Half of a Yellow Sun. New York: Anchor Books, 2006.

Danticat, Edwidge. The Dew Breaker. New York: Vintage, 2005.

Desai, Kiran. The Inheritance of Loss. New York: Grove Press, 2006.

Divakaruni, Chitra Banerjee. The Unknown Errors of Our Lives: Stories. New York: Doubleday, 2001.

Ghosh, Amitav. The Shadow Lines. Boston: Houghton Mifflin Company, 2005.

Jen, Gish. Typical American. Boston: Houghton Mifflin, 1991.

Kingston, Maxine. The Woman Warrior: Memoirs of a Girlhood Among Ghosts. New York: Vintage, 1989.

Lahiri, Jhumpa. The Interpreter of Maladies. Boston: Houghton Mifflin Company, 1999.

Lee, Chang Rae. Native Speaker. New York: Riverhead Books, 1995.

McGahan, Andrew. The White Earth. New York: Soho, 2006.

Morrison, Toni. Paradise. New York: Alfred A. Knopf, 1998.

Mukherjee, Bharati. The Middleman and Other Stories. New York: Grove Press, 1989.

Naipaul, V.S. Half a Life. New York: Alfred A. Knopf, 2001. . Magic Seeds. New York: Alfred A. Knopf, 2004.

Rushdie, Salman. Midnight's Children. New York: Vintage, 1995. The Satanic Verses. New York: Viking, 1989.

Upadhyay, Samrat. The Guru of Love. Boston: Houghton Mifflin Company, 2003. . The Royal Ghosts: Stories. Boston: Houghton Mifflin Company, 2006.

Viramontes, Helena Maria. Under the Feet of Jesus. New York: Plume, 1996.

Theory and Criticism

Aciman, Andre, ed. Letters of Transit. New York: The New Press, 1999.

Adorno, Theodor. Minima Moralia: Reflection on a Damaged Life. Trans. E. F. N. Jepycott.

London: Verso, 2005.

Anzaldua, Gloria. Borderlands/La Frontera. San Francisco: Aunt Lute Books, 1987.

Appadurai, Arjun. Fear of Small Numbers: An Essay on the Geography of Anger. Durham:

Duke UP, 2005.

Bhabha, Homi. The Location of Culture. London: Routledge, 1993. 
Bloom, Harold, ed. Salman Rushdie. Philadelphia: Chelsea House, 2003.

Braziel, Jana Evans and Anita Mannur, eds. Theorizing Diaspora. Malden, MA: Blackwell Publishing, 2003.

Fanon, Frantz. Black Skin White Mask. Trans. Charles Lam Markmann. New York: Grove Press, 1967.

Gramsci, Antonio. The Antonio Gramsci Reader: Selected Writings 1916-35. New York: NYU Press, 2000.

Guha, Ranajit, ed. Subaltern Studies IV: Writings on South Asian History and Society. Delhi: Oxford UP, 1985.

Horkheimer, Max and Theodor Adorno. Dialectics of Enlightenment. Trans. John Cumming.

New York: Continuum, 2001.

Morrison, Toni. Playing in the Dark: Whiteness and the Literary Imagination. New York: Vintage Books, 1993.

Prakash, Gyan, ed. After Colonialism: Imperial Histories and Postcolonial Displacements.

Princeton, New Jersey: Princeton UP, 1995.

Rushdie, Salman. Imaginary Homelands. London: Granta Books, 1991.

Said, Edward. Reflection on Exile and Other Essays. Cambridge, Massachusetts: Harvard UP, 2000.

Strehle, Susan. Transnational Women's Fiction. Basingstoke, UK: Palgrave Macmillan, 2008. 